Article

\title{
Vegetation Structure Index (VSI): Retrieving Vegetation Structural Information from Multi-Angular Satellite Remote Sensing
}

\author{
Ram C. Sharma (D)
}

check for updates

Citation: Sharma, R.C. Vegetation Structure Index (VSI): Retrieving Vegetation Structural Information from Multi-Angular Satellite Remote Sensing. J. Imaging 2021, 7, 84. https://doi.org/10.3390/ jimaging7050084

Academic Editor: Raimondo Schettini

Received: 9 March 2021

Accepted: 5 May 2021

Published: 9 May 2021

Publisher's Note: MDPI stays neutral with regard to jurisdictional claims in published maps and institutional affiliations.

Copyright: (C) 2021 by the author. Licensee MDPI, Basel, Switzerland. This article is an open access article distributed under the terms and conditions of the Creative Commons Attribution (CC BY) license (https:// creativecommons.org/licenses/by/ $4.0 /)$.
Department of Informatics, Tokyo University of Information Sciences, 4-1 Onaridai, Wakaba-ku, Chiba 265-8501, Japan; sharma@rsch.tuis.ac.jp; Tel.: +81-43-236-4603

\begin{abstract}
Utilization of the Bidirectional Reflectance Distribution Function (BRDF) model parameters obtained from the multi-angular remote sensing is one of the approaches for the retrieval of vegetation structural information. In this research, the potential of multi-angular vegetation indices, formulated by the combination of multi-spectral reflectance from different view angles, for the retrieval of forest above-ground biomass was assessed in the New England region. The multiangular vegetation indices were generated by the simulation of the Moderate Resolution Imaging Spectroradiometer (MODIS) BRDF/Albedo Model Parameters Product (MCD43A1 Version 6)-based BRDF parameters. The effects of the seasonal (spring, summer, autumn, and winter) composites of the multi-angular vegetation indices on the above-ground biomass, the angular relationship of the spectral reflectance with above-ground biomass, and the interrelationships between the multi-angular vegetation indices were analyzed. Among the existing multi-angular vegetation indices, only the Nadir BRDF-adjusted NDVI and Hot-spot incorporated NDVI showed significant relationship (more than $50 \%$ ) with the above-ground biomass. The Vegetation Structure Index (VSI), newly proposed in the research, performed in the most efficient way and explained $64 \%$ variation of the above-ground biomass, suggesting that the right choice of the spectral channel and observation geometry should be considered for improving the estimates of the above-ground biomass. In addition, the right choice of seasonal data (summer) was found to be important for estimating the forest biomass, while other seasonal data were either insensitive or pointless. The promising results shown by the VSI suggest that it could be an appropriate candidate for monitoring vegetation structure from the multi-angular satellite remote sensing.
\end{abstract}

Keywords: forests; structure; biomass; BRDF; MODIS; multi-angular; NDVI (fore-back); vegetation structure index

\section{Introduction}

Forests have experienced dramatic changes in terms of cover, density, and biomass worldwide. Monitoring of forest biomass and carbon stock changes is vital to comprehend deforestation and degradation conditions that have implications for the climate system. At local scales, forest structural parameters such as diameter at breast height, canopy height, etc., can be obtained from the measurement of individual trees. Then, the forest biomass can be estimated with allometric functions, which provides a functional relationship with easily measured variables such as standing tree height and diameter at breast height [1,2] However, satellite remote sensing is an expected technology for upscaling the in situ estimates of forest biomass into broad scales.

Multi-angular remote sensing refers to the observation of surface reflectance from multiple view angles beyond nadir alone with the account of solar position as well. It provides a technique of measuring anisotropic surface reflectance of the land surface. The anisotropic reflectance, the directional dependency of the reflectance with sun-sensor geometry, is a unique characteristic of the land surface [3-6]. Researchers have developed 
some Bidirectional Reflectance Distribution Function (BRDF) models such as computer simulation [7], empirical [8], physical radiative transfer [9], physical geometric optical [10, $11]$, and semi-emperical $[12,13]$ to describe the anisotropic characteristics of the land surface. Since the bidirectional reflectance is sensitive to vegetation structure (canopy cover, height, volume, etc.) $[14,15]$, it can be one of the approaches for the retrieval of above-ground biomass. The multi-angular remote sensing has also been utilized for characterization of biomes [16], forests [17], agricultural landscape [18], vegetation physiognomic types [19], and chemical attributes of the canopy $[20,21]$. On the other hand, the angular variation adds noise and uncertainty on the study of land surface biophysical parameters such as land cover and vegetation classification and phenology [22-24]. The BRDF models have many applications such as normalizing the BRDF effects of images taken at multiple sun-sensor geometry, estimation of albedo by integration of multi-angular reflectance, and retrieval of land surface attributes by the interpretation of BRDF shapes [25-27]. Therefore, more observations and research in the field of BRDF are necessary for better understanding the land-surface anisotropic characteristics and accurate retrieval of structural information.

For the retrieval of vegetation biophysical parameters from the multi-angular remote sensing, different approaches such as radiative transfer modeling [7], geometric-optical modeling [10], spectral invariant [28,29] and BRDF model parameters [30,31] have been attempted by the researchers. The Ross-Thick/Li-Sparse-Reciprocal (RTLSR) is one of the semi-empirical BRDF models. In this model, the bi-directional reflectance $(\mathrm{R})$ is described for a given sun zenith angle (SZA), view zenith angle (VZA), and relative azimuth angle (RAA) with isotropic, volumetric and geometric scattering coefficients and the kernels for volumetric scattering and geometric scattering [32]. Radiative transfer models are effective to estimate the biophysical and biochemical properties of the forest canopy. However, utilization of multi-angular indices as the combination of spectral reflectance measured from multiple view angles can be an uncomplicated and straightforward technique to derive vegetation structure information. An overview of the multi-angular indices available in the literature has been presented in Table 1.

Table 1. Overview of the multi-angular vegetation indices available in the literature. The iso, $\mathrm{H}, \mathrm{N}$, and $\mathrm{D}$ refers to the configuration of the sun-sensor geometries at Nadir-sun Nadir-view, Hot-spot, Nadir, and Dark-spot, respectively.

\begin{tabular}{|c|c|c|c|}
\hline Multi-Angular Vegetation Indices & Formula & Reference & Target Areas \\
\hline Nadir BRDF-adjusted NDVI (NDVI $\left.I_{i s o}\right)$ & $\frac{N i r_{i s o}-\operatorname{Red}_{i s o}}{N i r_{0}+R e d .}$ & Schaaf et al. [33] & Vegetation parameters \\
\hline Anisotropy index $\left(A N I X_{R e d}\right)$ & $\begin{array}{l}N H_{\text {red }}+K e U_{i s o} \\
D \text { en }\end{array}$ & Sandmeier et al. [34] & Land cover types \\
\hline Anisotropy index $\left(A N I X_{N i r}\right)$ & $H_{\text {nir }}^{\text {red }}$ & Sandmeier et al. [34] & Land cover types \\
\hline Hot-spot dark-spot index $\left(H D S_{r e d}\right)$ & $\frac{H_{\text {red }}-D_{\text {red }}}{D_{\text {red }}}$ & Lacaze et al. [35] & Vegetation clumping \\
\hline $\begin{array}{l}\text { Normalized difference between hot-spot } \\
\text { and dark-spot index }\left(N D H D_{\text {nir }}\right)\end{array}$ & $\begin{array}{l}H_{\text {nir }}-D_{\text {nir }} \\
H_{\text {nir }}+D_{\text {nir }}\end{array}$ & Chen et al. [36] & Vegetation clumping \\
\hline Hot-spot dark-spot NDVI (NDVI $\left.I_{H D}\right)$ & $\frac{H_{n i r}-D_{r e d}}{H_{\text {nir }}+D_{\text {red }}}$ & Pocewicz et al. [37] & Leaf area index \\
\hline Hot-spot-incorporated NDVI (NDVI $\left.I_{H S}\right)$ & $\stackrel{H_{\text {nir }}+D_{\text {red }}}{N_{N D V I}} \times\left(1-H_{\text {red }}\right)$ & Pocewicz et al. [37] & Leaf area index \\
\hline
\end{tabular}

Derivation of more sensitive vegetation indices from multi-angular remote sensing data is important for better retrieval of the vegetation structural information. The major objectives of this research are to assess the potential of multi-angular vegetation indices for the retrieval of forest above-ground biomass, and to propose a more sensitive vegetation index for the estimation of above-ground biomass. The effects of seasonal composites of the multi-angular vegetation indices on above-ground biomass, angular relationship of the spectral reflectance with above-ground biomass, and the interrelationships between the multi-angular vegetation indices have also been discussed. 


\section{Materials and Methods}

\subsection{Study Areas and In Situ Data}

This research was implemented in the New England region where a high-quality forest inventory database is available [38]. The database constitutes the field measurements conducted in five forests in 2009. It includes forest inventory data from five forests: Harvard Forest (moist temperate), Howland Research Forest (mature evergreen), Hubbard Brook Experimental Forest (deciduous hardwoods), Bartlett Experimental Forest (deciduous hardwoods), and Penobscot Experimental Forest (mixed conifers and hardwoods). The above-ground biomass was calculated with diameter at breast height greater than $10 \mathrm{~cm}$ using the allometric function [1]. The heterogeneous sample plots mixed with other land cover types, such as built-up areas, water ponds, etc., were discarded from the analysis. Among 59 sample plots (1 ha size) available, 55 sample plots were selected for this analysis. Location map of the study sites and distribution of sample plots have been shown in Figure 1.

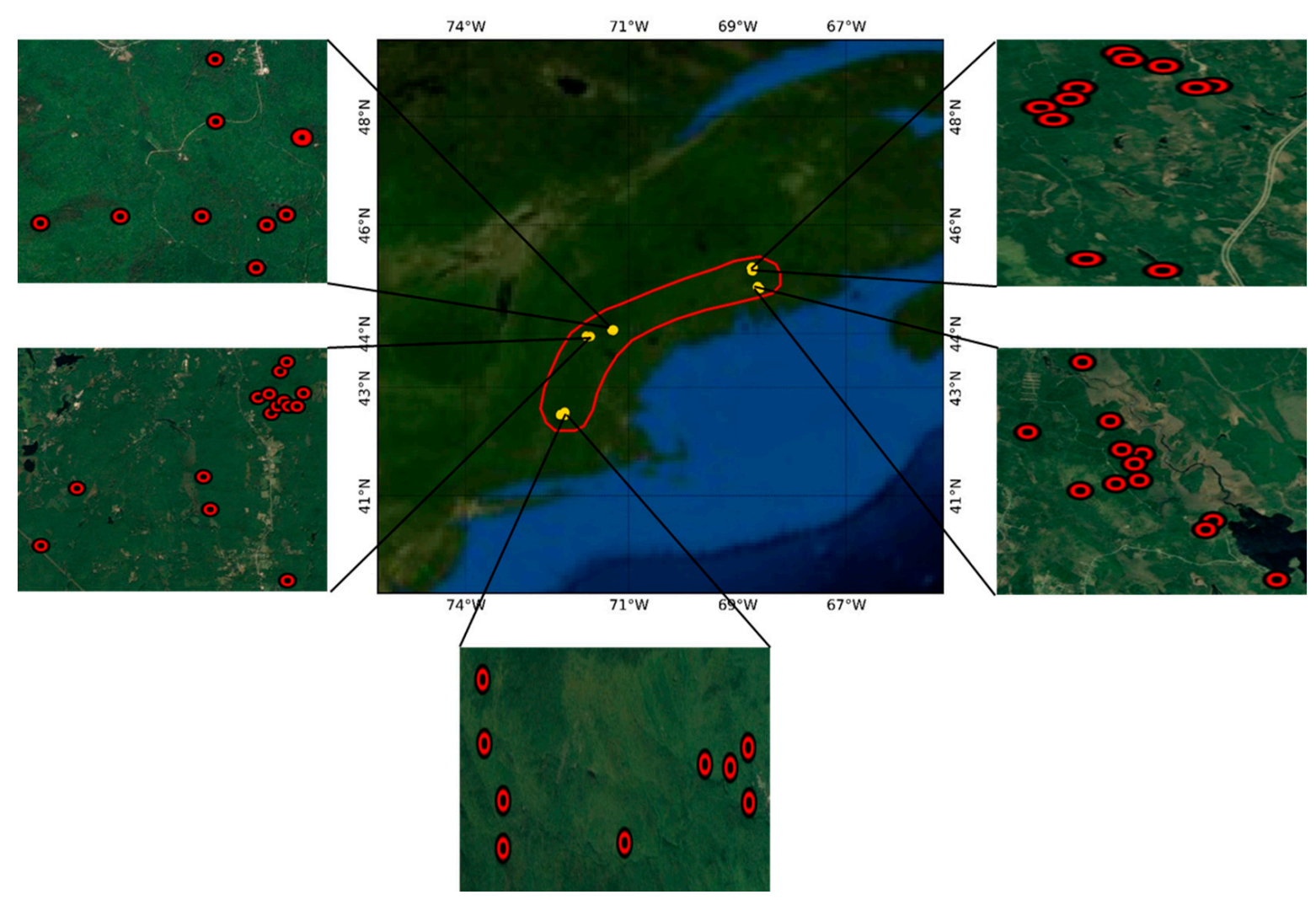

Figure 1. Location of the study sites and distribution of the sample plots.

\subsection{Proposal of New Multi-Angular Indices}

A typical forest canopy is composed of green canopy cover (sunlit crown and shadowed crown) and canopy shadow fraction (shadowed ground and shadowed crown). The fractional area of the canopy components vary significantly in the principal plane with respect to the view zenith angles [39]. The geometric configuration of (sun zenith angle, view zenith angle, and relative azimuth angle) has been used to define the concerned sunsensor geometries, such as Nadir-sun and Nadir-view $\left(0^{\circ}, 0^{\circ}, 0^{\circ}\right)$, Hot-spot $\left(45^{\circ}, 45^{\circ}, 0^{\circ}\right)$, Nadir $\left(45^{\circ}, 0^{\circ}, 0^{\circ}\right)$, and Dark-spot $\left(45^{\circ}, 45^{\circ}, 180^{\circ}\right)$. While the scene viewed from the backscattering direction is mostly composed of sunlit ground and sunlit crown, the shadowed crown and shadowed ground dominate the scene viewed from the fore-scattering direction. Red reflectance at the Back-scattering direction is sensitive to hiding of the ground which should be faster in tall and dense (high-biomass) canopy [40]. The larger the ground surface 
hidden by canopies, the lower the red reflectance at the Back-scattering direction. For tall and dense canopy, near infrared reflectance at the Fore-scattering direction should be higher due to the effect of leaf area index changes. In this research assumed hot-spot $\left(45^{\circ}\right.$, $\left.45^{\circ}, 0^{\circ}\right)$ and dark-spot $\left(45^{\circ}, 45^{\circ}, 180^{\circ}\right)$ were used as the Back-scattering and Fore-scattering directions, respectively. Fore-scattering (Fore) and Back-scattering (Back) Normalized Difference Vegetation Index (NDVI $\left.I_{\text {Fore-back }}\right)$ can be calculated as the normalized difference between the Near Infrared (Nir) reflectance observed at Fore-scattering (Fore) direction and the Red reflectance (Red) observed at Back-scattering (Back) direction (Equation (1)) to be sensitive to the volumetric structure of the forest canopy. Then, by integrating the non-linear interaction of the vegetation coverage ratio, indicated by the term $\left(1-\operatorname{Nir}_{\text {Fore }}\right)$, the Vegetation Structure Index (VSI) has been proposed in the research (Equation (1)).

$$
V S I=\frac{N D V I_{\text {Fore-back }}}{1-\text { Nir Fore }_{\text {For }}}
$$

\subsection{Processing of Satellite Data}

The Moderate Resolution Imaging Spectroradiometer (MODIS) BRDF/Albedo Model Parameters Product (MCD43A1) has been providing BRDF model parameters based on the RTLSR model [33]. The BRDF model parameters (isotropic, volumetric and geometric coefficients) were obtained from the MODIS BRDF/Albedo product (MCD43A1 Version 6) of 2009. This dataset is produced daily using 16 days of Terra and Aqua MODIS data at a 500-m $(\mathrm{m})$ resolution. Using the central geolocation point of each plot, the BRDF model parameters were extracted for a single MODIS pixel. Then, the bidirectional reflectance for the assumed Hot-spot $\left(45^{\circ}, 45^{\circ}, 0^{\circ}\right)$, Nadir $\left(45^{\circ}, 0^{\circ}, 0^{\circ}\right)$, and Dark-spot $\left(45^{\circ}\right.$, $45^{\circ}, 180^{\circ}$ ) were calculated by using the BRDF model parameters (isotropic, volumetric and geometric scattering coefficients) and look-up values for the kernels of volumetric scattering and geometric scattering. The Back-scattering and Fore-scattering reflectance were obtained from the assumed Hot-spot $\left(45^{\circ}, 45^{\circ}, 0^{\circ}\right)$ and Dark-spot $\left(45^{\circ}, 45^{\circ}, 180^{\circ}\right)$ geometries, respectively. Seasonal median composites, spring (March-May), summer (June-August), autumn (September-November), and winter (December-February), were generated from the daily calculations of the multi-angular vegetation indices.

\section{Results}

\subsection{Performance of Existing Multi-Angular Indices}

The performance of the multi-angular vegetation indices was assessed using linear regression analysis with the in situ above-ground biomass data in terms of Coefficient of determination $\left(\mathrm{R}^{2}\right)$ and Root Mean Square Error (RMSE). The relationships between existing multi-angular spectral indices and above-ground biomass have been shown in Figure 2, and the results have also been summarized in Table 2.

As shown in Table 3, only the Nadir BRDF-adjusted NDVI (NDVI $\left.I_{i s o}\right)$ and Hot-spotincorporated NDVI (NDVI $I_{H S}$ ) showed a significant relationship (more than 50\%) with the above-ground biomass. Other multi-angular vegetation indices, Anisotropy index $\left(A N I X_{R e d}\right)$, Anisotropy index $\left(A N I X_{N i r}\right)$, Hot-spot dark spot index $\left(H D S_{r e d}\right)$, Normalized difference between hot-spot and dark-spot index $\left(N D H D_{n i r}\right)$, and Hot-spot dark-spot NDVI $\left(N D V I_{H D}\right)$ did not show sensitivity towards the above-ground biomass.

The correlation matrix of the extant multi-angular indices has been shown in Figure 3. Among the seven extant multi-angular indices, the highly correlated pairs were (i) ANIX $X_{\text {Nir }}$ and $N D H D_{\text {nir }}$ (ii) $A N I X_{\text {Red }}$ and $H D S_{\text {red }}$ (iii) $N D V I_{\text {iso }}$ and $N D V I_{H S}$. This analysis confirms that only a few extant multi-angular indices are important for the estimation of aboveground biomass. 


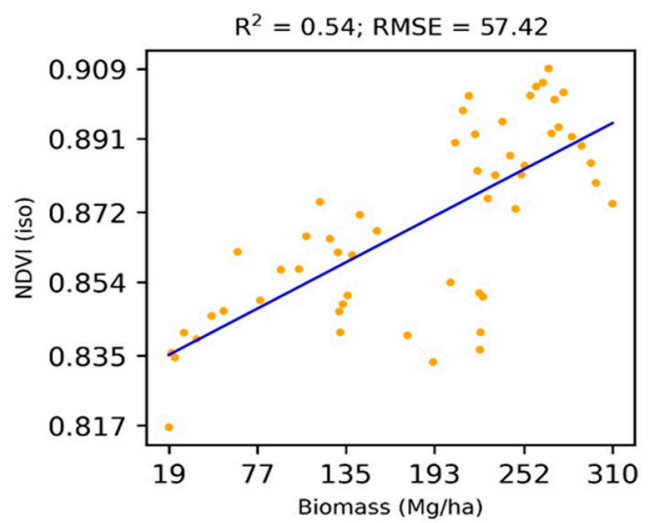

(a)

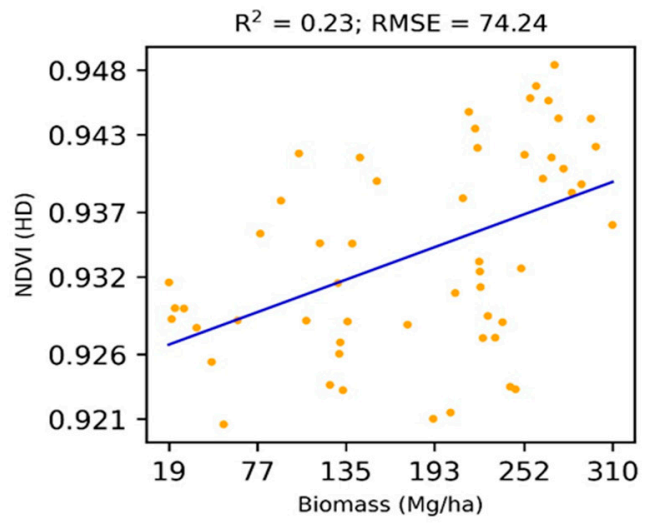

(c)

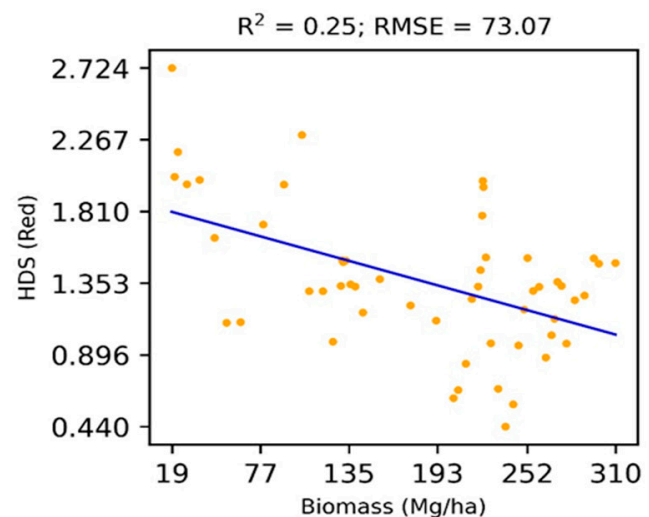

(e)

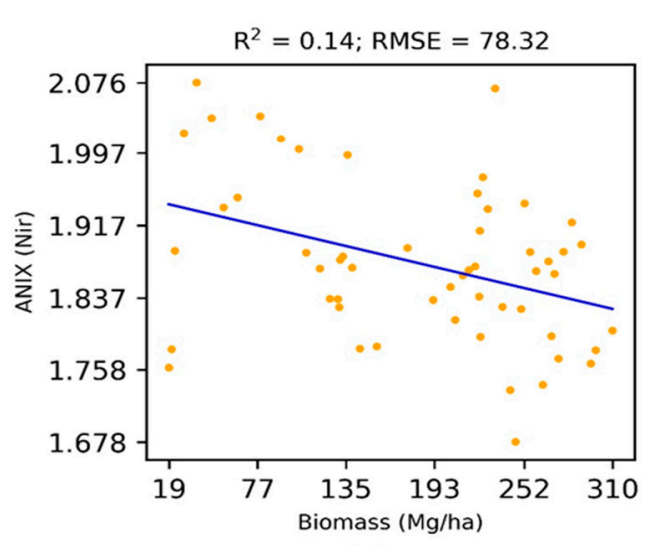

(g)

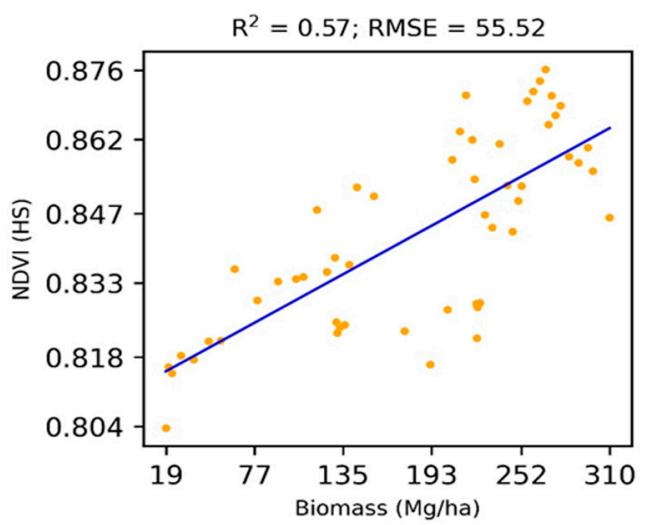

(b)

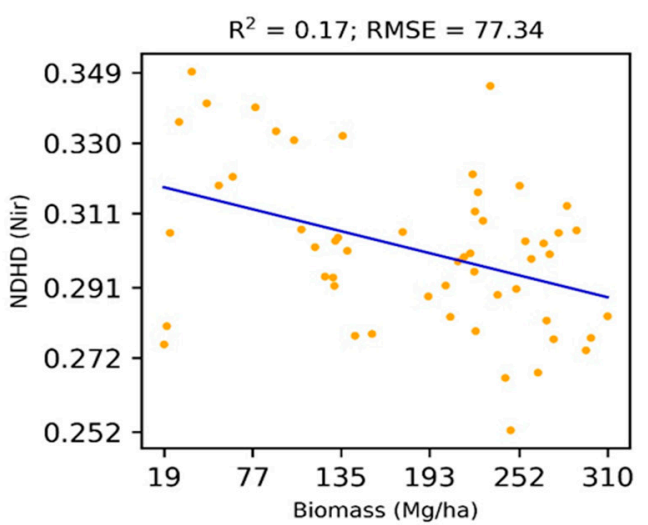

(d)

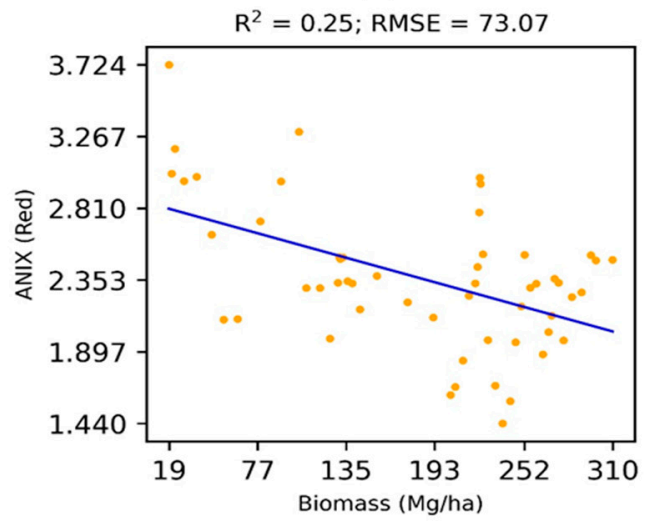

(f) 
Table 2. Performance of existing multi-angular vegetation indices.

\begin{tabular}{ccc}
\hline Multi-Angular Vegetation Indices & $\mathbf{R}^{\mathbf{2}}$ & RMSE \\
\hline Anisotropy index $\left(A N I X_{\text {Red }}\right)$ & 0.25 & 73.07 \\
Anisotropy index $\left(A N I X_{N i r}\right)$ & 0.14 & 78.32 \\
Hot-spot dark spot index $\left(H D S_{\text {red }}\right)$ & 0.25 & 73.07 \\
Normalized difference between hot-spot & 0.17 & 77.34 \\
and dark-spot index $\left(N D H D_{\text {nir }}\right)$ & 0.23 & 74.24 \\
Hot-spot dark-spot NDVI $\left(N D V I_{H D}\right)$ & 0.57 & 55.52 \\
Hot-spot incorporated NDVI (NDVI $\left.I_{H S}\right)$ & 0.54 & 57.42 \\
Nadir BRDF-adjusted NDVI $\left(N D V I_{i s o}\right)$ & & \\
\hline
\end{tabular}

Table 3. Calculation of nonparametric rank correlation $p$-values.

\begin{tabular}{ccc}
\hline $\begin{array}{c}\text { Multi-Angular Indices and } \\
\text { Reflectances }\end{array}$ & $\begin{array}{c}\text { Spearman's Rank } \\
\text { Correlation } \\
\boldsymbol{p} \text {-Value }\end{array}$ & $\begin{array}{c}\text { Kendall's Rank } \\
\text { Correlation } \\
\boldsymbol{p} \text {-Value }\end{array}$ \\
\hline Anisotropy index $\left(A N I X_{\text {Red }}\right)$ & 0.005527 & 0.008450 \\
\hline Anisotropy index $\left(A N I X_{\text {Nir }}\right)$ & 0.015114 & 0.014109 \\
\hline $\begin{array}{c}\text { Normalized difference between hot-spot } \\
\text { and dark-spot index }\left(N D H D_{\text {nir }}\right)\end{array}$ & 0.005527 & 0.008450 \\
\hline Hot-spot dark-spot NDVI $\left(N D V I_{H D}\right)$ & 0.009190 & 0.008829 \\
\hline Hot-spot incorporated NDVI $\left(N D V I_{H S}\right)$ & 0.000148 & 0.001236 \\
\hline Nadir BRDF-adjusted NDVI $\left(N D V I_{i s o}\right)$ & 0.000000 & 0.000000 \\
\hline Near infrared (Back-scattering) & 0.000000 & 0.000000 \\
\hline Near infrared (Nadir) & 0.000000 & 0.000001 \\
\hline Near infrared (Fore-scattering) & 0.000000 & 0.000000 \\
\hline Red (Back-scattering) & 0.000000 & 0.000000 \\
\hline Red (Nadir) & 0.000001 & 0.000006 \\
\hline Red (Fore-scattering) & 0.000317 & 0.000333 \\
\hline Fore-scattering Back-scattering NDVI \\
$\left(N D V I_{\text {Fore-back }}\right)$
\end{tabular}

\subsection{Performance of New Multi-Angular Indices}

The $N D V I_{\text {Fore-back }}$ showed higher sensitivity $\left(\mathrm{R}^{2}=0.62, \mathrm{RMSE}=52.46\right)$ towards the above-ground biomass than existing multi-angular vegetation indices (Table 2). Furthermore, the Vegetation Structure Index (VSI) proposed in the research performed in the most efficient way explaining $64 \%$ variation $\left(R^{2}=0.64, R M S E=51.14\right)$ of the above-ground biomass (Figure 4).

\subsection{Effects of View Angles on Biomass}

The effects of the view angles (Fore-scattering versus Back-scattering) on the aboveground biomass have been shown in Figure 5.

For the Red reflectance: the Back-scattering direction was found to be more sensitive $\left(\mathrm{R}^{2}=0.47, \mathrm{RMSE}=61.72\right)$ to the above-ground biomass than the nadir direction, whereas the Fore-scattering direction was quite insensitive. Both the Back-scattering and Nadir reflectance were inversely proportional to the above-ground biomass. In contrast, for the Near Infrared reflectance, the Fore-scattering direction was found to be more sensitive $\left(\mathrm{R}^{2}=0.59, \mathrm{RMSE}=54.19\right)$ to the above-ground biomass than the Back-scattering and Nadir directions. All three directions (Fore-scattering, Back-scattering, and Nadir) were directly 
proportional to the above-ground biomass. Therefore, the right choice of the spectral channel and observation geometry should be considered for improving the estimates of above-ground biomass. It should be noted that the $N D V I_{\text {Fore-back }}$ has been built by integrating the most sensitive spectral channel and observation geometry.

The correlation matrix of the red and near infrared reflectance measured at different angular configurations (Back-scattering, Nadir, and Fore-scattering) has been shown in Figure 6. The correlation matrix showed that near infrared reflectance was highly correlated across different angular configurations (Back-scattering, Nadir, and Fore-scattering) in the principle plane than the red reflectance.

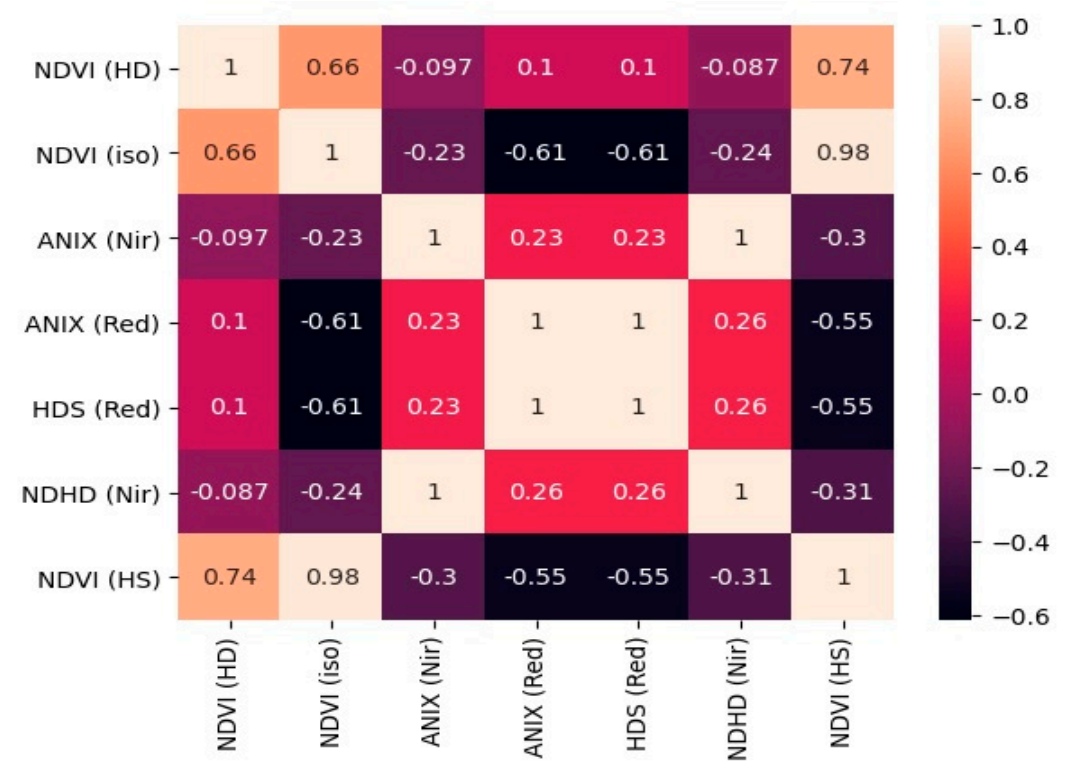

Figure 3. Correlation matrix of the extant multi-angular vegetation indices.

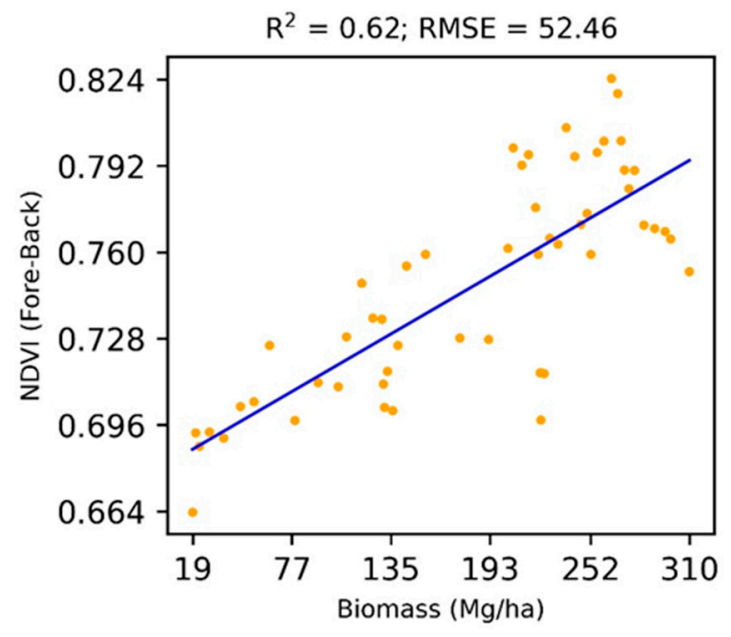

(a)

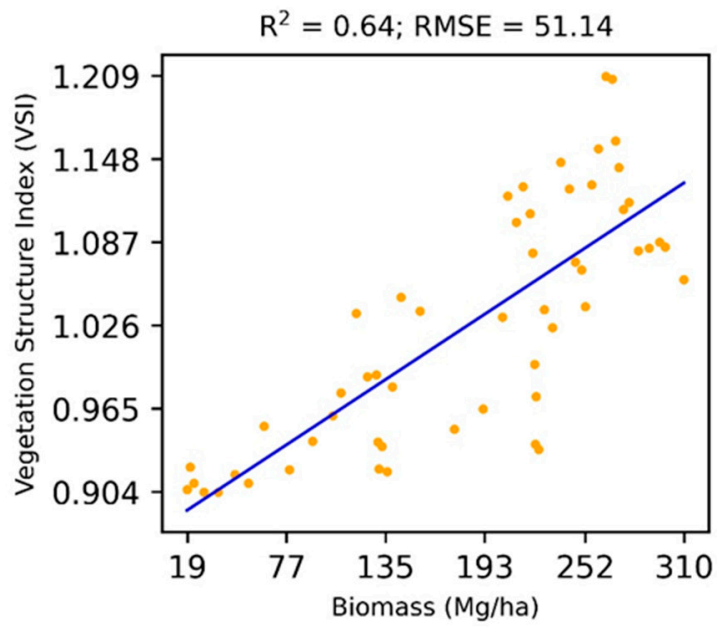

(b)

Figure 4. Performance of new multi-angular vegetation indices for the estimation of above-ground biomass. 


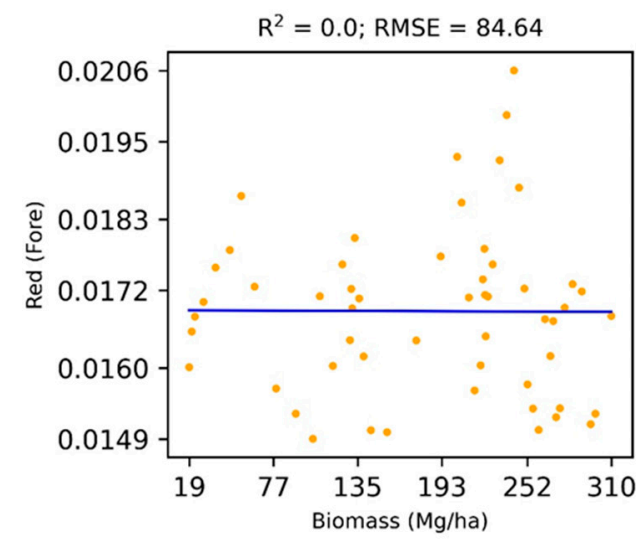

(a)

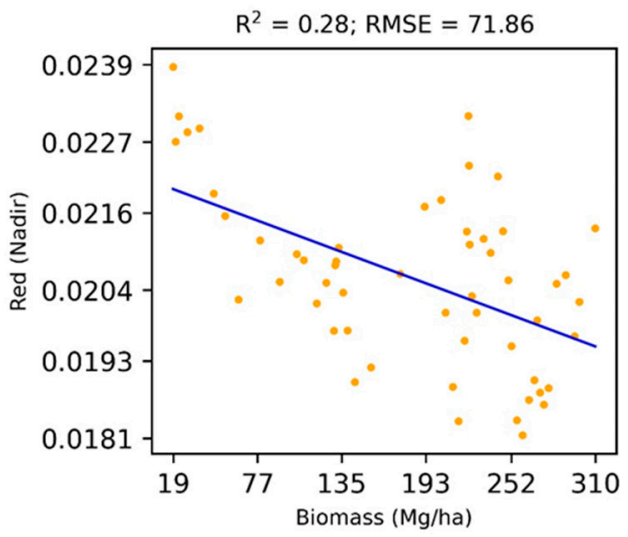

(c)

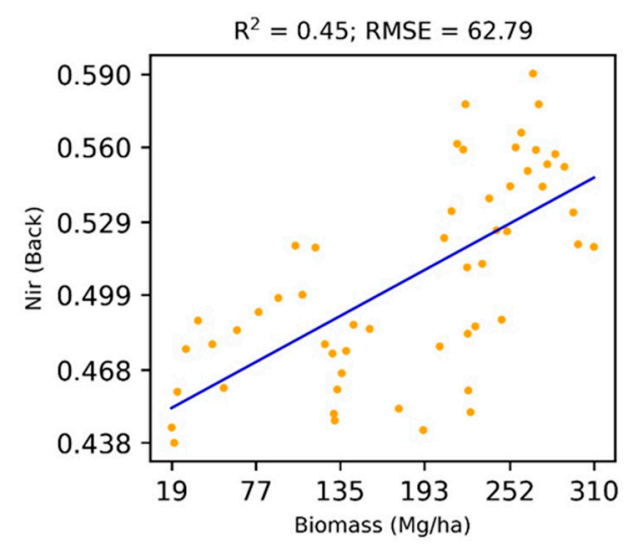

(e)

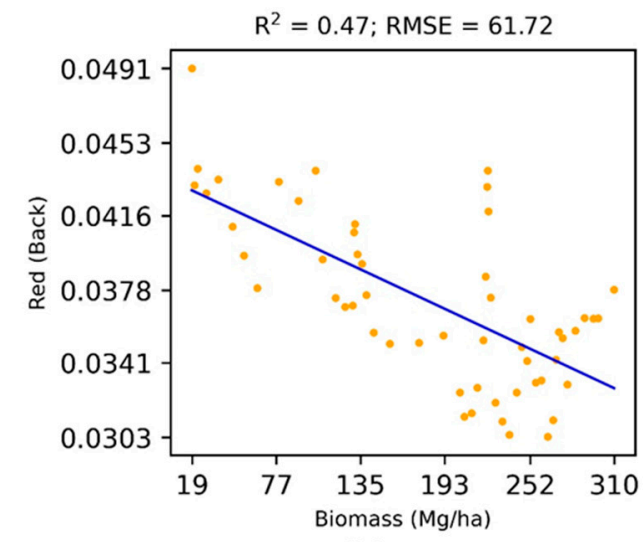

(b)

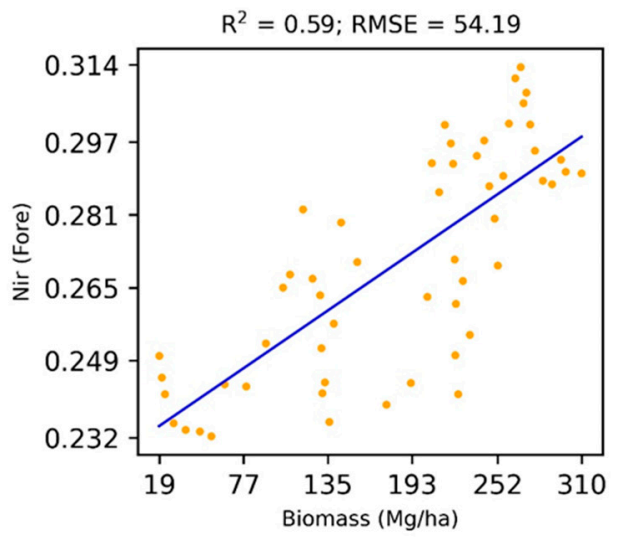

(d)

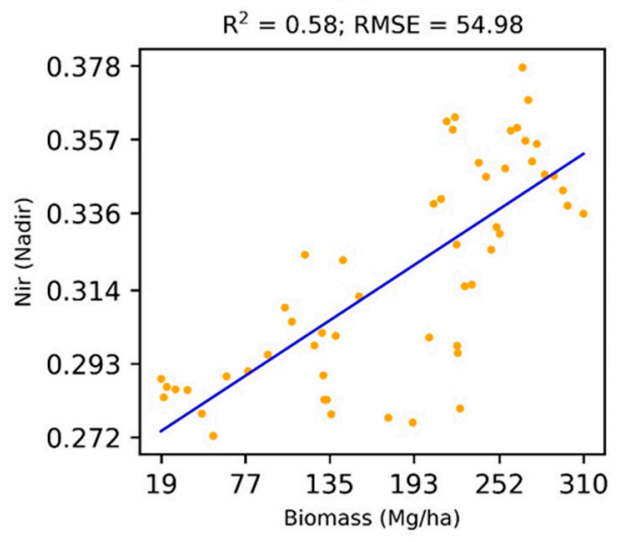

(f)

Figure 5. Effects of view angles on the above-ground biomass.

\subsection{Interrelationships between Structural Indices}

Figure 7 shows the interrelationships between multi-angular structural indices. $N D V I_{\text {Fore-back }}$ was more related to the $N D V I_{\text {iso }}$ than the $N D V I_{H D}$. Nevertheless, $N D V I_{\text {Fore-back }}$ and $N D V I_{H D}$ were quite distinct with lower coefficient of determination $\left(\mathrm{R}^{2}=0.27\right)$. The relationship between VSI and $N D V I_{i s o}$ was lower $\left(\mathrm{R}^{2}=0.88\right)$ than that of $N D V I_{\text {Fore-back }}$ and $N D V I_{\text {iso }}$. Still, the newly proposed index in the research was quite distinct from the existing indices while being more sensitive towards the aboveground biomass. 


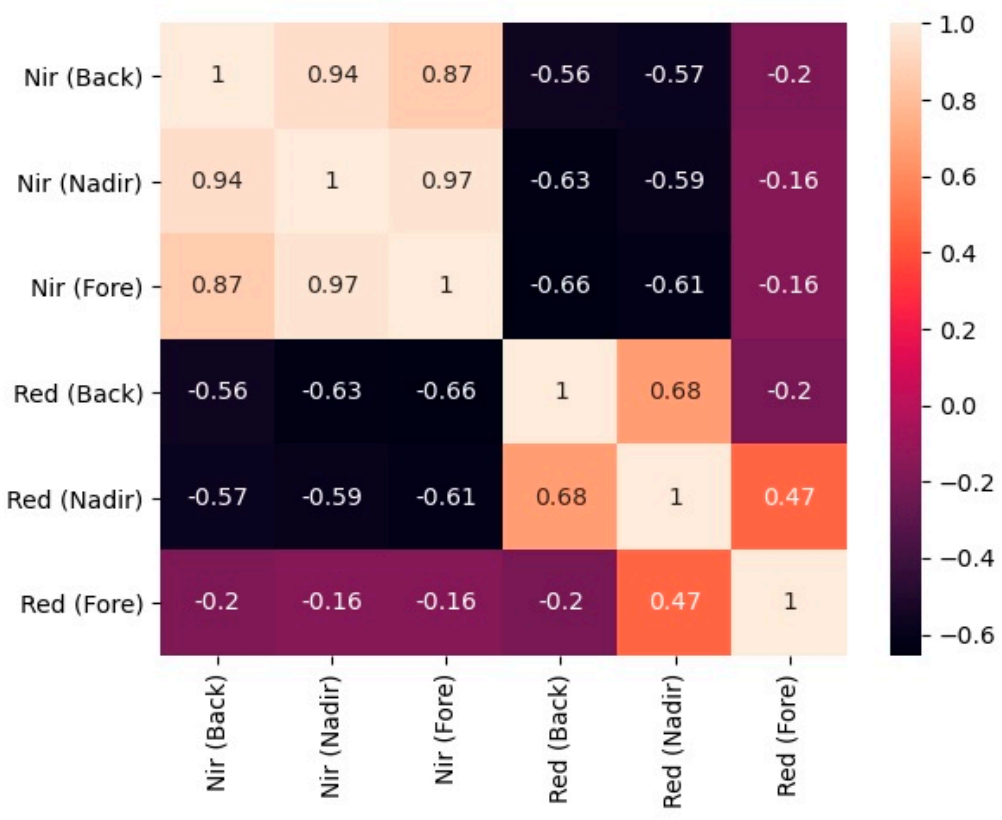

Figure 6. Correlation matrix of the reflectances measured at different angular configurations in the principle plane.

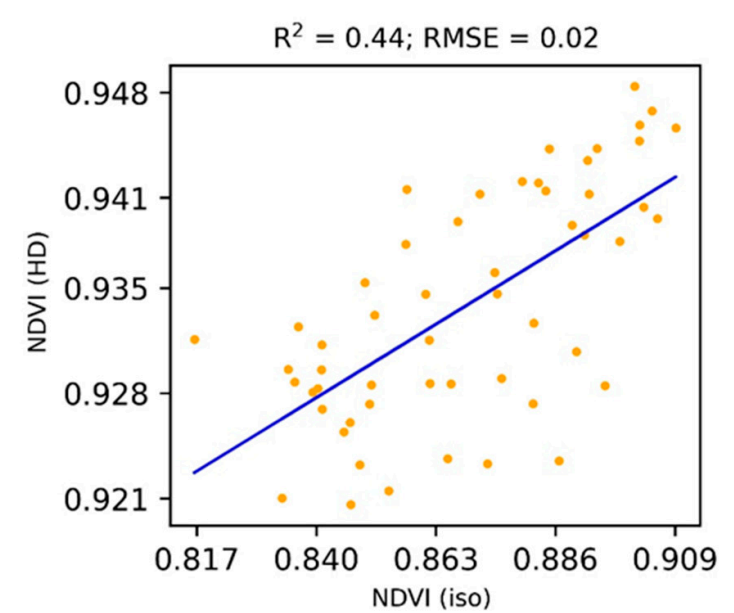

(a)

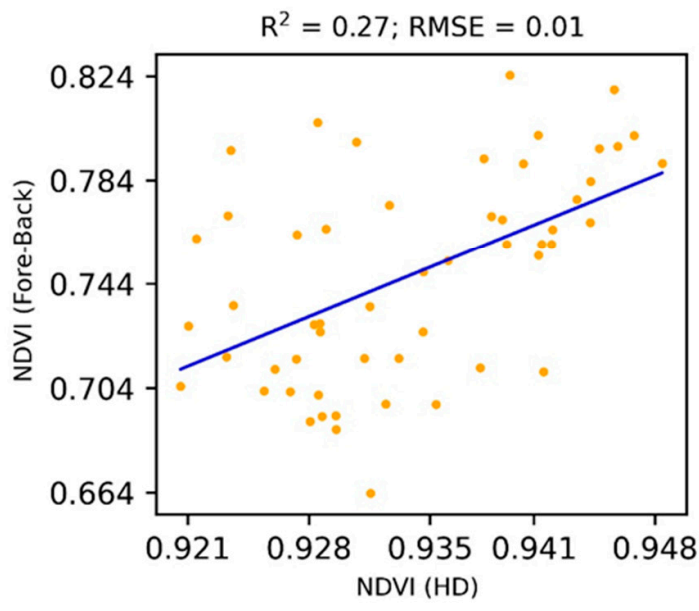

(c)

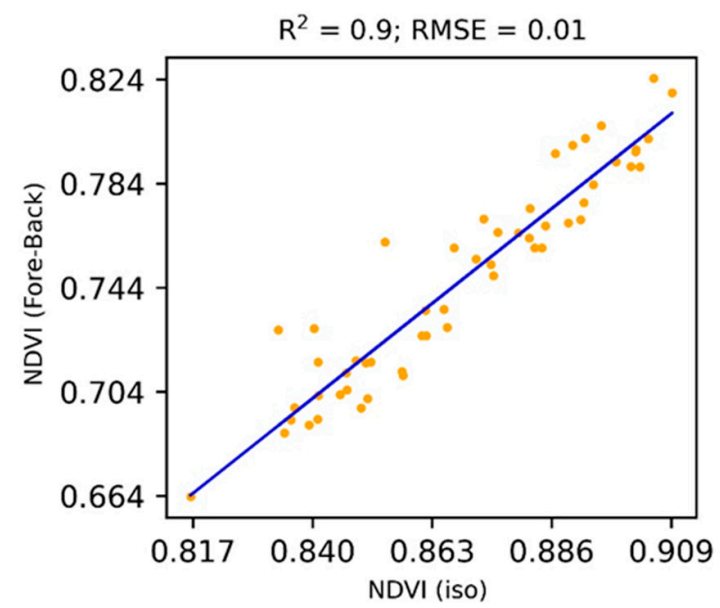

(b)

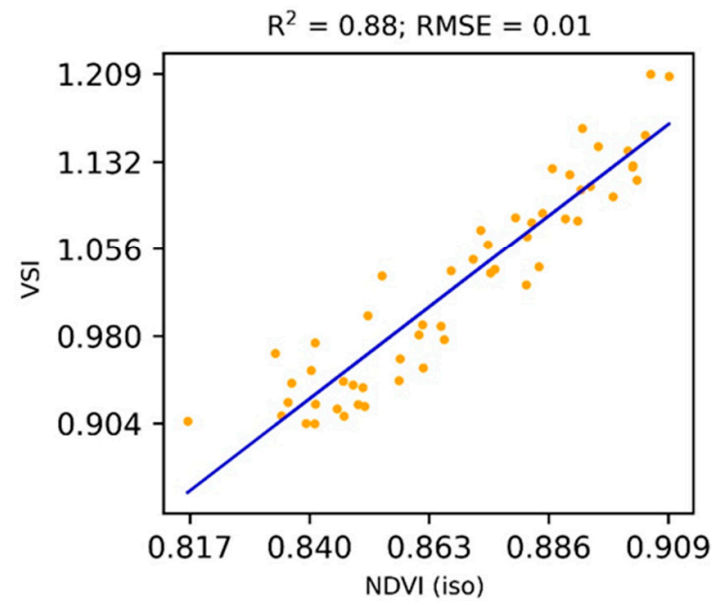

(d)

Figure 7. Interrelationships between multi-angular indices. 


\subsection{Effects of Seasonal Data on Biomass}

The analysis on above (Sections 3.1-3.4) were based on median composites of the reflectance in the summer season. Figures 8 and 9 show the seasonal effects of multi-angular vegetation indices (NDVI $I_{i s o}$ and VSI) on the above-ground biomass. Both the $N D V I_{i s o}$ and VSI in summer were most sensitive to the above-ground biomass, whereas other seasons were either insensitive (winter season) or pointless (spring and autumn seasons with a decreasing trend). Therefore, the right choice of seasonal data was found to be important for estimating the forest biomass.

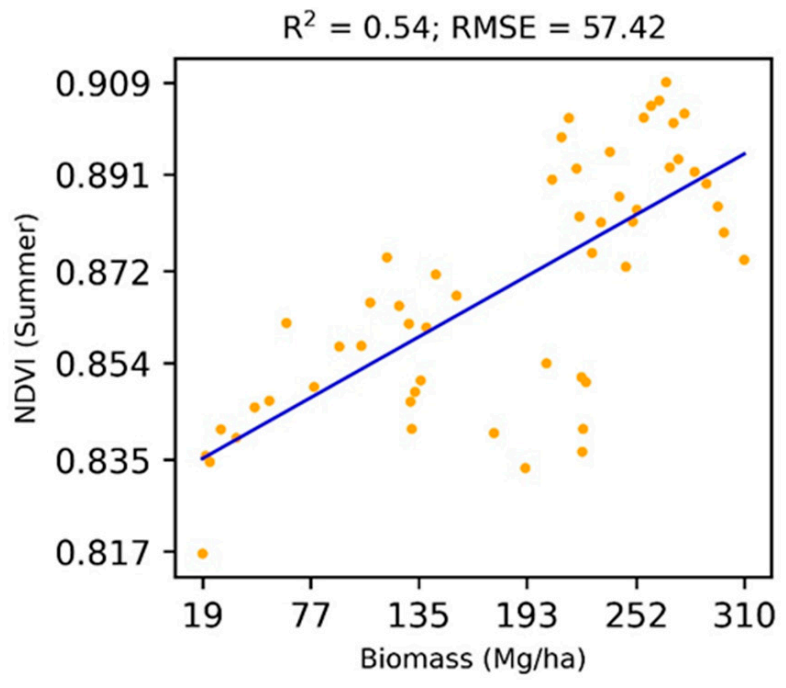

(a)

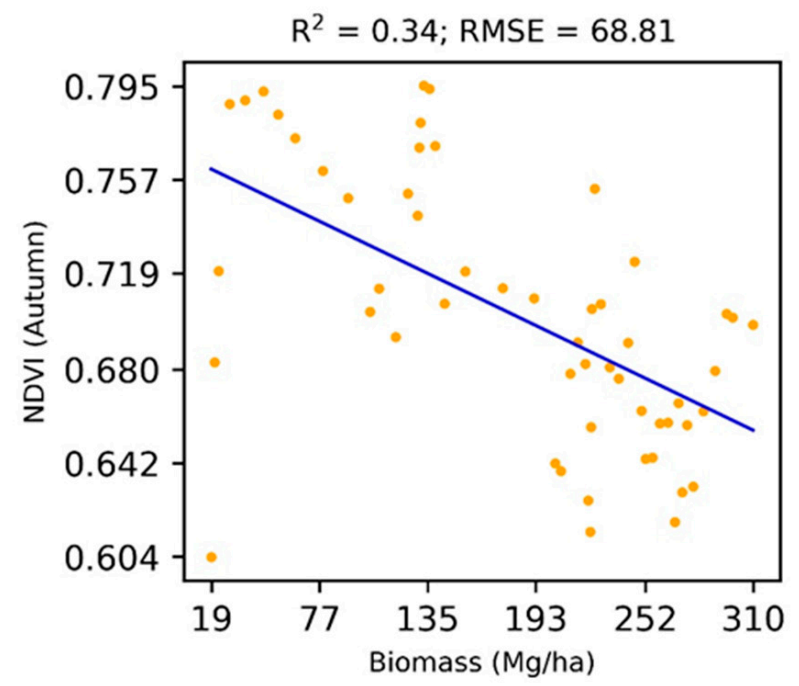

(c)

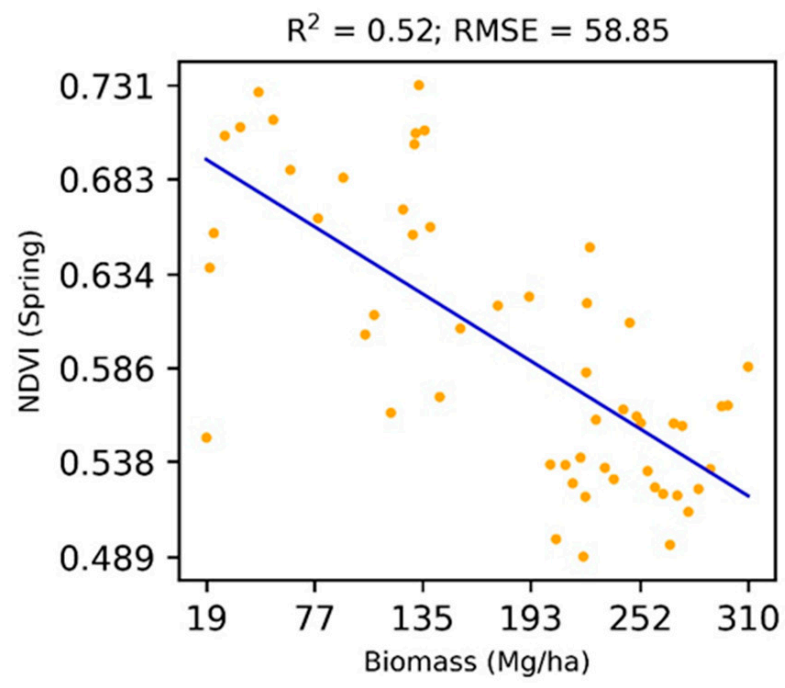

(b)

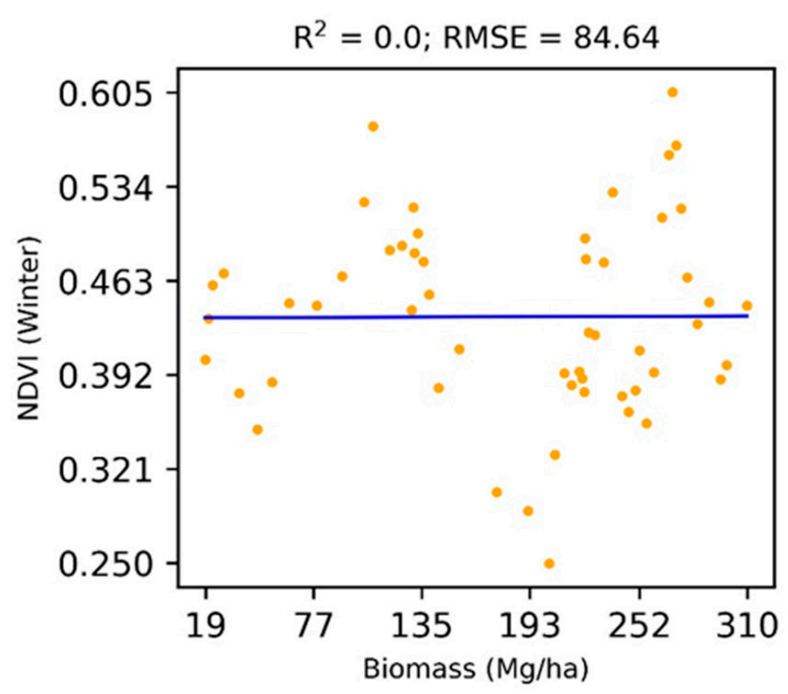

(d)

Figure 8. Effects of seasonal NDVI (iso) on the above-ground biomass.

\subsection{Statistical Significance Results}

The D'Agostino and Pearson's normality test and Shapiro-Wilk test were performed to confirm if the distribution of the available data is normal or not. The $p$-values for the D'Agostino and Pearson's normality test and Shapiro-Wilk test were 0.019513 and 0.002633 , respectively. Since the $p$-values of both tests were less than 0.05 ( $95 \%$ confidence), data 
were not distributed normally. Therefore, nonparametric statistical tests (Spearman's rank correlation, Kendall's rank correlation, and Kruskal-Wallis H-test) that do not assume a specific distribution to the data were performed to confirm significance of the linear regression coefficients reported. Associated $p$-values of the Spearman's rank correlation and Kendall's rank correlation have been shown in Table 3 for all independent variables concerned. Regardless of the low coefficient of determination $\left(R^{2}\right)$ values of the extant multi-angular indices (Table 2) and multi-angular reflectances (Figure 5) and the associated regression model, which could not explain much of the variation of data, all of them were significantly correlated to the above-ground biomass with $p$-value $>0.05$ ( $95 \%$ confidence) except the Red reflectance at Fore-scattering direction ( $p$-values $=0.564852,0.692547$ ). Nevertheless, the newly proposed Vegetation Structure Index (VSI) with highest $R^{2}$ value and low $p$-value (0.000000) was able to explain much of the variation of the above-ground biomass data.

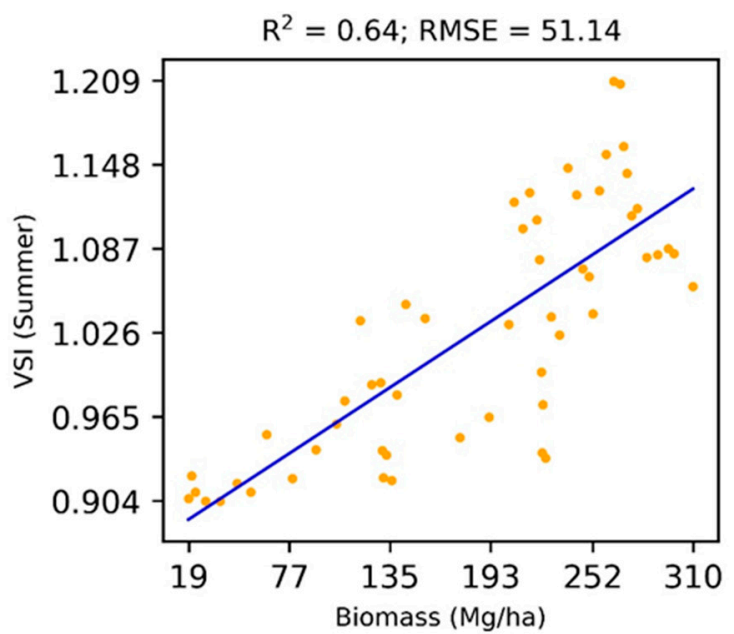

(a)

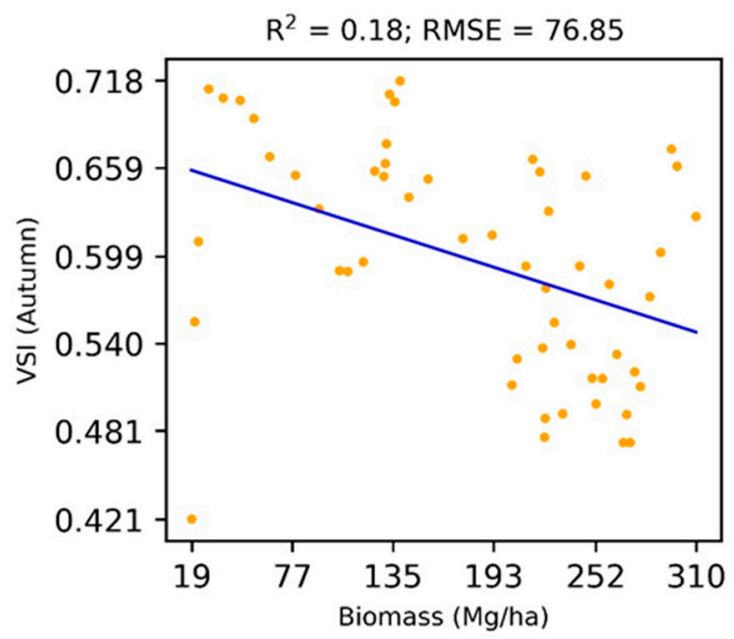

(c)

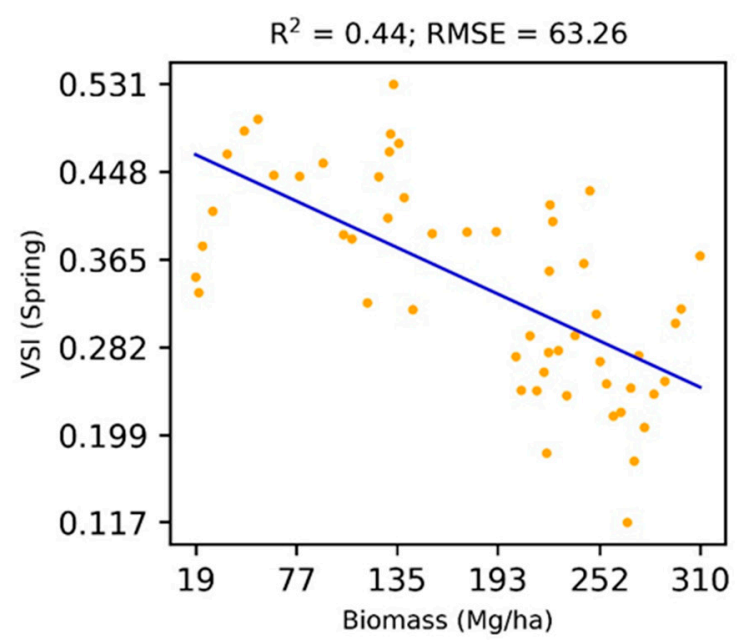

(b)

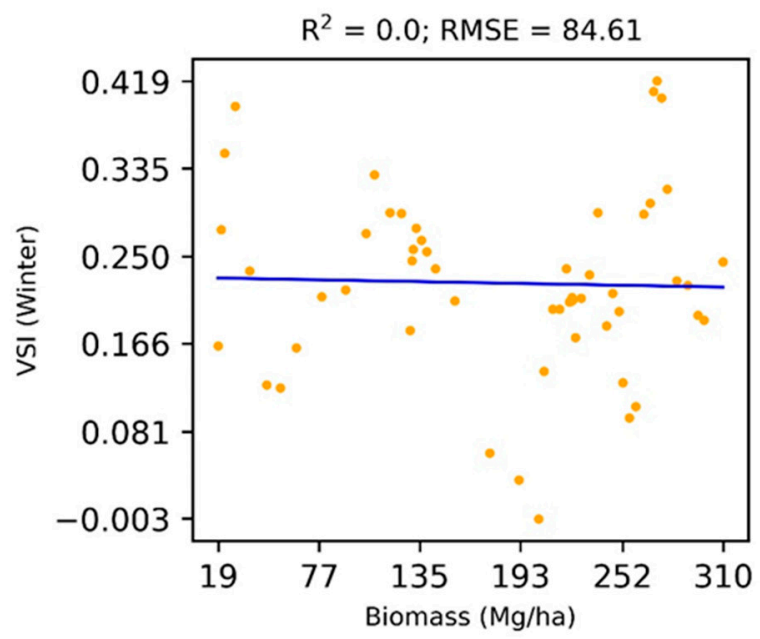

(d)

Figure 9. Effects of seasonal VSI on the above-ground biomass.

\section{Discussion}

There is an increased need for improved retrieval of canopy structural information from remote sensing data. The optical-imagery-based metrics have been useful to generate canopy structural attributes in different forests [41,42]. Radiative transfer models 
have shown efficient performance on the estimation of canopy gap fraction and biochemistry $[43,44]$. The multi-angular remote sensing datasets have a particular capability of capturing structural information and enable wider applications in ecology and terrestrial monitoring [45-47]. The spectral indices derived from multi-angular observations are promising techniques that can be used to obtain vegetation structural attributes [48-50].

Some previous studies have demonstrated the utility of multi-angular reflectance measurements for assessing vegetation structure such as leaf area index, canopy clumping, etc. [51,52]. In this research, we evaluated the performance of seven extant multi-angular vegetation indices for the estimation of above-ground biomass. Among them, the hot-spot incorporated NDVI ( $\left.N D V I_{H S}\right)$ proposed by Pocewicz et al. [37] could estimate the aboveground biomass in the most efficient manner $\left(R^{2}=0.57\right.$, RMSE $\left.=55.22\right)$. However, it should be noted that none of the extant multi-angular indices were proposed for the estimation of above-ground biomass. The $N D V I_{H S}$ was proposed for the estimation of leaf area index. Wang et al. [53] tested angular and band effects on forest biomass retrieval and found that off-nadir vegetation indices could predict the forest biomass more accurately than the nadir. Cui et al. [54] also emphasized typical angle reflectances for estimating canopy heights. In line with these studies, the proposal of VSI for the sole purpose of deriving volumetric structure of the canopy (above-ground biomass) is a timely and significant contribution.

Field survey data are important for biomass modeling research. In this research, aboveground biomass data selected from five forests in the New England region ranged from 18.72 to $309.76 \mathrm{Mg} / \mathrm{ha}$ with a mean value of $182.62 \mathrm{Mg} / \mathrm{ha}$, which was considered quite diverse for the assessment of multi-angular vegetation indices. Choi et al. [55] used this dataset to evaluate waveform lidar-based canopy height metrics. Similarly, Park et al. [56] utilized this dataset for examining the canopy heights estimated from waveform lidar data. Wang et al. [57] also utilized this dataset for validating the global estimation of forest canopy height. These research studies show the feasibility of this dataset for assessing the potential of multi-angular vegetation indices.

\section{Conclusions}

In this research, the Vegetation Structure Index (VSI) was proposed based on the concept that higher near-infrared reflectance in the fore-scattering direction indicates exposure of higher contents of the canopy volume, whereas lower red reflectance in the back-scattering direction indicates suppression of the ground reflectance with higher contents of the canopy volume. The VSI was found to be more sensitive to the aboveground biomass in the New England forests than other extant multi-angular vegetation indices. Achieving 7\% increase in the estimation of above-ground biomass over the extant multi-angular indices by the VSI is considerable. It suggests that the right choice of the spectral channel and observation geometry should be considered for improving the estimates of the above-ground biomass. In addition, the right choice of seasonal data (summer) was found to be important for estimating the forest biomass while other seasonal data were either insensitive or pointless. The VSI has been derived from the MODIS-based BRDF parameters which can be generated all over the globe. Availability of much higher resolution bi-directional reflectance data is expected in the future for improved estimates of the above-ground biomass in the field of multi-angular satellite remote sensing.

Funding: This research received no funding.

Institutional Review Board Statement: Not applicable.

Informed Consent Statement: Not applicable.

Data Availability Statement: Not applicable.

Acknowledgments: MODIS data used in the research were available from the NASA EOSDIS Land Processes Distributed Active Archive Center (LP DAAC). The author is thankful to anonymous reviewers and editors of the journal.

Conflicts of Interest: The author declares no conflict of interest. 


\section{References}

1. Jenkins, J.C.; Chojnacky, D.C.; Heath, L.S.; Birdsey, R.A. Comprehensive Database of Diameter-Based Biomass Regressions for North American Tree Species; United States Department of Agriculture, Forest Service, Northeastern Research Station: Newtown Square, PA, USA, 2004; p. 319.

2. Chave, J.; Condit, R.; Aguilar, S.; Hernandez, A.; Lao, S.; Perez, R. Error Propagation and Scaling for Tropical Forest Biomass Estimates. Philos. Trans. R. Soc. Lond. Ser. B Biol. Sci. 2004, 359, 409-420. [CrossRef]

3. Kimes, D.S.; Newcomb, W.W.; Nelson, R.F.; Schutt, J.B. Directional Reflectance Distributions of a Hardwood and Pine Forest Canopy. IEEE Trans. Geosci. Remote Sens. 1986, GE-24, 281-293. [CrossRef]

4. Li, X.; Strahler, A.H. Geometric-Optical Bidirectional Reflectance Modeling of the Discrete Crown Vegetation Canopy: Effect of Crown Shape and Mutual Shadowing. IEEE Trans. Geosci. Remote Sens. 1992, 30, 276-292. [CrossRef]

5. Sandmeier, S.; Deering, D.W. Structure Analysis and Classification of Boreal Forests Using Airborne Hyperspectral BRDF Data from ASAS. Remote Sens. Environ. 1999, 69, 281-295. [CrossRef]

6. Gerard, F.F.; North, P.R.J. Analyzing the Effect of Structural Variability and Canopy Gaps on Forest BRDF Using a GeometricOptical Model. Remote Sens. Environ. 1997, 62, 46-62. [CrossRef]

7. North, P.R.J. Three-Dimensional Forest Light Interaction Model Using a Monte Carlo Method. IEEE Trans. Geosci. Remote Sens. 1996, 34, 946-956. [CrossRef]

8. Walthall, C. A Study of Reflectance Anisotropy and Canopy Structure Using a Simple Empirical Model. Remote Sens. Environ. 1997, 61, 118-128. [CrossRef]

9. Liang, S.; Strahler, A. Retrieval of Surface BRDF from Multiangle Remotely Sensed Data. Remote Sens. Environ. 1994, 50, 18-30. [CrossRef]

10. Li, X.; Strahler, A. Geometric-Optical Modeling of a Conifer Forest Canopy. IEEE Trans. Geosci. Remote Sens. 1985, GE-23, 705-721. [CrossRef]

11. Jupp, D.L.B.; Strahler, A.H. A Hotspot Model for Leaf Canopies. Remote Sens. Environ. 1991, 38, 193-210. [CrossRef]

12. Lavergne, T.; Kaminski, T.; Pinty, B.; Taberner, M.; Gobron, N.; Verstraete, M.M.; Vossbeck, M.; Widlowski, J.-L.; Giering, R. Application to MISR Land Products of an RPV Model Inversion Package Using Adjoint and Hessian Codes. Remote Sens. Environ. 2007, 107, 362-375. [CrossRef]

13. Roujean, J.-L.; Leroy, M.; Deschamps, P.-Y. A Bidirectional Reflectance Model of the Earth's Surface for the Correction of Remote Sensing Data. J. Geophys. Res. 1992, 97, 20455. [CrossRef]

14. Asner, G.P. Contributions of Multi-view Angle Remote Sensing to Land-surface and Biogeochemical Research. Remote Sens. Rev. 2000, 18, 137-162. [CrossRef]

15. Chopping, M.; Schaaf, C.B.; Zhao, F.; Wang, Z.; Nolin, A.W.; Moisen, G.G.; Martonchik, J.V.; Bull, M. Forest Structure and Aboveground Biomass in the Southwestern United States from MODIS and MISR. Remote Sens. Environ. 2011, 115, $2943-2953$. [CrossRef]

16. Bacour, C.; Bréon, F.-M. Variability of Biome Reflectance Directional Signatures as Seen by POLDER. Remote Sens. Environ. 2005, 98, 80-95. [CrossRef]

17. Rautiainen, M.; Lang, M.; Mõttus, M.; Kuusk, A.; Nilson, T.; Kuusk, J.; Lükk, T. Multi-Angular Reflectance Properties of a Hemiboreal Forest: An Analysis Using CHRIS PROBA Data. Remote Sens. Environ. 2008, 112, 2627-2642. [CrossRef]

18. Román, M.O.; Gatebe, C.K.; Schaaf, C.B.; Poudyal, R.; Wang, Z.; King, M.D. Variability in Surface BRDF at Different Spatial Scales (30 m-500 m) over a Mixed Agricultural Landscape as Retrieved from Airborne and Satellite Spectral Measurements. Remote Sens. Environ. 2011, 115, 2184-2203. [CrossRef]

19. Sharma, R.; Hara, K. Characterization of Vegetation Physiognomic Types Using Bidirectional Reflectance Data. Geosciences 2018, 8, 394. [CrossRef]

20. Song, X.; Feng, W.; He, L.; Xu, D.; Zhang, H.-Y.; Li, X.; Wang, Z.-J.; Coburn, C.A.; Wang, C.-Y.; Guo, T.-C. Examining View Angle Effects on Leaf N Estimation in Wheat Using Field Reflectance Spectroscopy. ISPRS J. Photogramm. Remote Sens. 2016, $122,57-67$. [CrossRef]

21. Liu, X.; Liu, L. Influence of the Canopy BRDF Characteristics and Illumination Conditions on the Retrieval of Solar-Induced Chlorophyll Fluorescence. Int. J. Remote Sens. 2018, 39, 1782-1799. [CrossRef]

22. Jackson, R.D.; Teillet, P.M.; Slater, P.N.; Fedosejevs, G.; Jasinski, M.F.; Aase, J.K.; Moran, M.S. Bidirectional Measurements of Surface Reflectance for View Angle Corrections of Oblique Imagery. Remote Sens. Environ. 1990, 32, 189-202. [CrossRef]

23. Leroy, M.; Roujean, J.-L. Sun and View Angle Corrections on Reflectances Derived from NOAA/AVHRR Data. IEEE Trans. Geosci. Remote Sens. 1994, 32, 684-697. [CrossRef]

24. Verrelst, J.; Schaepman, M.E.; Koetz, B.; Kneubühler, M. Angular Sensitivity Analysis of Vegetation Indices Derived from CHRIS/PROBA Data. Remote Sens. Environ. 2008, 112, 2341-2353. [CrossRef]

25. Lucht, W.; Schaaf, C.B.; Strahler, A.H. An Algorithm for the Retrieval of Albedo from Space Using Semiempirical BRDF Models. IEEE Trans. Geosci. Remote Sens. 2000, 38, 977-998. [CrossRef]

26. Jiao, Z.; Hill, M.J.; Schaaf, C.B.; Zhang, H.; Wang, Z.; Li, X. An Anisotropic Flat Index (AFX) to Derive BRDF Archetypes from MODIS. Remote Sens. Environ. 2014, 141, 168-187. [CrossRef]

27. Gao, F. Detecting Vegetation Structure Using a Kernel-Based BRDF Model. Remote Sens. Environ. 2003, 86, 198-205. [CrossRef] 
28. Schull, M.A.; Knyazikhin, Y.; Xu, L.; Samanta, A.; Carmona, P.L.; Lepine, L.; Jenkins, J.P.; Ganguly, S.; Myneni, R.B. Canopy Spectral Invariants, Part 2: Application to Classification of Forest Types from Hyperspectral Data. J. Quant. Spectrosc. Radiat. Transf. 2011, 112, 736-750. [CrossRef]

29. Lewis, P.; Disney, M. Spectral Invariants and Scattering across Multiple Scales from Within-Leaf to Canopy. Remote Sens. Environ. 2007, 109, 196-206. [CrossRef]

30. d'Entremont, R.P.; Schaaf, C.B.; Lucht, W.; Strahler, A.H. Retrieval of Red Spectral Albedo and Bidirectional Reflectance Using AVHRR HRPT and GOES Satellite Observations of the New England Region. J. Geophys. Res. Atmos. 1999, 104, 6229-6239. [CrossRef]

31. Doll, C.N.H.; Muller, J.-P.; Schaaf, C.; Strahler, A.H. Feng Gao Mapping Urban Landcover Using the Bidirectional Reflectance Distribution Function BRDF/Albedo Product from the Moderate Resolution Imaging Spectroradiometer (MODIS). In Proceedings of the IGARSS 2001. Scanning the Present and Resolving the Future. IEEE 2001 International Geoscience and Remote Sensing Symposium (Cat. No.01CH37217), Sydney, NSW, Australia, 9-3 July 2001; Volume 6, pp. 2680-2682.

32. Wanner, W.; Li, X.; Strahler, A.H. On the Derivation of Kernels for Kernel-Driven Models of Bidirectional Reflectance. J. Geophys. Res. 1995, 100, 21077. [CrossRef]

33. Schaaf, C.B.; Gao, F.; Strahler, A.H.; Lucht, W.; Li, X.; Tsang, T.; Strugnell, N.C.; Zhang, X.; Jin, Y.; Muller, J.-P.; et al. First Operational BRDF, Albedo Nadir Reflectance Products from MODIS. Remote Sens. Environ. 2002, 83, 135-148. [CrossRef]

34. Sandmeier, S.; Müller, C.; Hosgood, B.; Andreoli, G. Physical Mechanisms in Hyperspectral BRDF Data of Grass and Watercress. Remote Sens. Environ. 1998, 66, 222-233. [CrossRef]

35. Lacaze, R. Retrieval of Vegetation Clumping Index Using Hot Spot Signatures Measured by POLDER Instrument. Remote Sens. Environ. 2002, 79, 84-95. [CrossRef]

36. Chen, J.M.; Menges, C.H.; Leblanc, S.G. Global Mapping of Foliage Clumping Index Using Multi-Angular Satellite Data. Remote Sens. Environ. 2005, 97, 447-457. [CrossRef]

37. Pocewicz, A.; Vierling, L.A.; Lentile, L.B.; Smith, R. View Angle Effects on Relationships between MISR Vegetation Indices and Leaf Area Index in a Recently Burned Ponderosa Pine Forest. Remote Sens. Environ. 2007, 107, 322-333. [CrossRef]

38. Cook, B.; Dubayah, R.; Griffith, P.; Hall, F.G.; Nelson, R.; Ranson, J.; Simard, M.; Siqueira, P.; Strahler, A.H. NACP New England and Sierra National Forests Biophysical Measurements: 2008-2010. ORNL DAAC 2011. [CrossRef]

39. Sharma, R.C.; Kajiwara, K.; Honda, Y. Automated Extraction of Canopy Shadow Fraction Using Unmanned Helicopter-Based Color Vegetation Indices. Trees 2013, 27, 675-684. [CrossRef]

40. Sharma, R.C.; Kajiwara, K.; Honda, Y. Estimation of Forest Canopy Structural Parameters Using Kernel-Driven Bi-Directional Reflectance Model Based Multi-Angular Vegetation Indices. Isprs J. Photogramm. Remote Sens. 2013, 78, 50-57. [CrossRef]

41. Fatehi, P.; Damm, A.; Schaepman, M.; Kneubühler, M. Estimation of Alpine Forest Structural Variables from Imaging Spectrometer Data. Remote Sens. 2015, 7, 16315-16338. [CrossRef]

42. Huesca, M.; García, M.; Roth, K.L.; Casas, A.; Ustin, S.L. Canopy Structural Attributes Derived from AVIRIS Imaging Spectroscopy Data in a Mixed Broadleaf/Conifer Forest. Remote Sens. Environ. 2016, 182, 208-226. [CrossRef]

43. Schlerf, M.; Atzberger, C. Inversion of a Forest Reflectance Model to Estimate Structural Canopy Variables from Hyperspectral Remote Sensing Data. Remote Sens. Environ. 2006, 100, 281-294. [CrossRef]

44. Miraglio, T.; Adeline, K.; Huesca, M.; Ustin, S.; Briottet, X. Joint Use of PROSAIL and DART for Fast LUT Building: Application to Gap Fraction and Leaf Biochemistry Estimations over Sparse Oak Stands. Remote Sens. 2020, 12, 2925. [CrossRef]

45. Schaepman, M.E.; Koetz, B.; Schaepman-Strub, G.; Itten, K.I. Spectrodirectional Remote Sensing for the Improved Estimation of Biophysical and -Chemical Variables: Two Case Studies. Int. J. Appl. Earth Obs. Geoinf. 2005, 6, 271-282. [CrossRef]

46. Hilker, T.; Coops, N.C.; Coggins, S.B.; Wulder, M.A.; Brown, M.; Black, T.A.; Nesic, Z.; Lessard, D. Detection of Foliage Conditions and Disturbance from Multi-Angular High Spectral Resolution Remote Sensing. Remote Sens. Environ. 2009, 113, 421-434. [CrossRef]

47. Fassnachta, F.; Koch, B. Review of Forestry Oriented Multi-Angular Remote Sensing Techniques. Int. Forest. Rev. 2012, 14, 285-298. [CrossRef]

48. Pisek, J.; Chen, J.M.; Lacaze, R.; Sonnentag, O.; Alikas, K. Expanding Global Mapping of the Foliage Clumping Index with Multi-Angular POLDER Three Measurements: Evaluation and Topographic Compensation. ISPRS J. Photogramm. Remote Sens. 2010, 65, 341-346. [CrossRef]

49. Hilker, T.; Gitelson, A.; Coops, N.C.; Hall, F.G.; Black, T.A. Tracking Plant Physiological Properties from Multi-Angular TowerBased Remote Sensing. Oecologia 2011, 165, 865-876. [CrossRef]

50. He, L.; Chen, J.M.; Pisek, J.; Schaaf, C.B.; Strahler, A.H. Global Clumping Index Map Derived from the MODIS BRDF Product. Remote Sens. Environ. 2012, 119, 118-130. [CrossRef]

51. Chen, J.M.; Liu, J.; Leblanc, S.G.; Lacaze, R.; Roujean, J.-L. Multi-Angular Optical Remote Sensing for Assessing Vegetation Structure and Carbon Absorption. Remote Sens. Environ. 2003, 84, 516-525. [CrossRef]

52. Wu, C.; Niu, Z.; Wang, J.; Gao, S.; Huang, W. Predicting Leaf Area Index in Wheat Using Angular Vegetation Indices Derived from in Situ Canopy Measurements. Can. J. Remote Sens. 2010, 36, 301-312. [CrossRef]

53. Wang, Q.; Pang, Y.; Li, Z.; Sun, G.; Chen, E.; Ni-Meister, W. The Potential of Forest Biomass Inversion Based on Vegetation Indices Using Multi-Angle CHRIS/PROBA Data. Remote Sens. 2016, 8, 891. [CrossRef] 
54. Cui, L.; Jiao, Z.; Dong, Y.; Sun, M.; Zhang, X.; Yin, S.; Ding, A.; Chang, Y.; Guo, J.; Xie, R. Estimating Forest Canopy Height Using MODIS BRDF Data Emphasizing Typical-Angle Reflectances. Remote Sens. 2019, 11, 2239. [CrossRef]

55. Choi, S.; Ni, X.; Shi, Y.; Ganguly, S.; Zhang, G.; Duong, H.; Lefsky, M.; Simard, M.; Saatchi, S.; Lee, S.; et al. Allometric Scaling and Resource Limitations Model of Tree Heights: Part 2. Site Based Testing of the Model. Remote Sens. 2013, 5, 202-223. [CrossRef]

56. Park, T.; Kennedy, R.; Choi, S.; Wu, J.; Lefsky, M.; Bi, J.; Mantooth, J.; Myneni, R.; Knyazikhin, Y. Application of Physically-Based Slope Correction for Maximum Forest Canopy Height Estimation Using Waveform Lidar across Different Footprint Sizes and Locations: Tests on LVIS and GLAS. Remote Sens. 2014, 6, 6566-6586. [CrossRef]

57. Wang, Y.; Li, G.; Ding, J.; Guo, Z.; Tang, S.; Wang, C.; Huang, Q.; Liu, R.; Chen, J.M. A Combined GLAS and MODIS Estimation of the Global Distribution of Mean Forest Canopy Height. Remote Sens. Environ. 2016, 174, 24-43. [CrossRef] 